\title{
SEC's Push Back On Adoption Of IFRS In The United States
}

RamMohan R. Yallapragada, Fayetteville State University, USA C. William Roe, Arkansas State University, USA

Alfred G. Toma, University of Louisiana, Lafayette, USA

\begin{abstract}
For a long time, the United States (US) Generally Accepted Accounting Principles (GAAP), are considered as the gold standard for financial reporting by companies all over the world. With the advent of globalization of capital markets and the proliferation of the multi-national corporations $(M N C s)$, there emerged a movement for developing a uniform set of accounting standards applicable to companies all over the world in order to achieve uniformity in financial reporting. The movement is initiated by the International Accounting Standards Board (IASB) which started to issue International Financial Reporting Standards (IFRS). Over the last decade, four alternative methods have been considered by the Securities and Exchange Commission (SEC) for a possible adoption of IFRS in the US: outright adoption, convergence, endorsement, and condorsement. Recently, the SEC appears to be taking a step backwards in its policy towards adoption of IFRS. The process involves prohibitive costs to US companies which are already suffering under the ill effects of a great recession. The adoption of IFRS would also impose enormous burden on the academia, the accounting profession, and the regulatory apparatus of the SEC. Also, there is a question as to whether a single set of international accounting standards applicable to all countries is even desirable. The FASB and the IASB have been working on convergence since 2002. The SEC began studying the pros and cons of adoption of IFRS since 2010. But, in its latest staff report, issued in July 2012, the SEC did not include any final policy decision as to whether IFRS will ever be adopted at all in any manner in the US. Furthermore, the SEC, in its report, made it very clear that turning over control of US accounting standardsetting authority to the IASB is out of question. This paper presents the various efforts made so far in aligning US GAAP with the IFRS and the future outlook regarding adoption of IFRS in the US.
\end{abstract}

Keywords: FASB; SEC; GAAP; IASB; IFRS; International Accounting Standards

\section{INTRODUCTION}

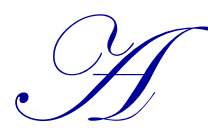

fter the stock market Crash of 1929, the United States (US) Congress enacted the Securities Act of 1933 and the Securities Exchange Act of 1934, establishing the Securities and Exchange Commission (SEC) to regulate business organizations in the US. The task of setting accounting standards to be followed by the companies was delegated by the SEC to various professional accounting organizations. These organizations, which included the Financial Accounting Standards Board (FASB) and its predecessors, began to issue authoritative rules and pronouncements of accounting procedures which together constituted the entire body known as the Generally Accepted Accounting Principles (GAAP) (Phillips, 2010). All these pronouncements, together known as the GAAP, are considered as the gold standard for financial accounting and reporting guidelines all over the world. Thus, in the US, there existed a comprehensive set of accounting standards firmly entrenched in place long before the establishment of the International Accounting Standards Committee in 1973 (Tyson, 2011). 


\section{ADVENT OF INTERNATIONAL FINANACIAL ACCOUNTING STANDARDS}

With the gradual proliferation of multinational corporations operating across borders, a global movement emerged among accounting professionals in various countries towards achieving convergence of GAAPs of different countries into a single set of uniform accounting procedures equally applicable to business firms in all countries in the world. The first step in the movement came in 1973 with the establishment of "International Accounting Standards Committee" (IASC), founded as a vehicle for harmonizing accounting practices throughout the world (Ruder et al., 2005). The International Accounting Standards Board (IASB) was formed in 2001 replacing IASC. The IASB operates under the oversight of the IFRS Foundation, with a mandate to develop and approve pronouncements known as International Financial Reporting Standards (IFRS) (Poon, 2010). As Blaszynski et al. (2012) state, even several decades ago, the International Organization of Securities Commissions (IOSCO) called for global accounting standards for cross-border financial reporting. The Sarbanes-Oxley Act of 2002 also instructed the SEC to consider the development of global accounting standards. At one point, the US GAAP appeared to be a likely choice for becoming the global standard. Instead, IFRS has emerged as a global set of accounting standards (Blaszynski et al., 2012).

This global wave for the wide spread adoption of IFRS received a huge fillip when the European Union (EU), comprising of half the world's economy, decided to adopt the IFRS. The IASB began to produce comprehensive and consistent accounting standards, mostly in conjunction with the FASB. The main objective of IFRS is to make international financial reporting comparisons as easy as possible (Gundewadi \& Paragouda, 2013). Over the past decade, more than 120 countries worldwide have committed to adopting IFRS. The US has been a key player in the global movement towards IFRS, "but it has acted in the unique role of a hyper influential outsider" (Ramana, 2012). At the same time, there has been a relative decline in the international prestige of the US GAAP. Many people claim that the US GAAP are rule-based while the IFRS are "principles based" and that the principlesbased system of IFRS would provide management with too much flexibility and auditors, with too little guidance (McEnroe \& Sullivan, 2012). It is also claimed that the US GAAP-based financial statements were not able to prevent the huge accounting scandals in the late 1990's. The Enron and WorldCom fiascos that decimated the world capital markets gave further strength to calls for a single set of high-quality global accounting standards (Tyson, 2011).

\section{IMPORTANT MILESTONES ON THE ROAD TO ADOPTION OF IFRS}

\section{October 2002: Norwalk Agreement}

The first important milestone occurred on September 18, 2002 when the FASB and the IASB at a joint meeting in Norwalk, signed an MOU (Memorandum of Understanding), famously known as the "Norwalk Agreement" (Legotte, 2012). The agreement formally recognized convergence as an avowed goal of these two standard-setters. Since then, the process has started for reducing differences between the US GAAP and IFRS, by means of several convergence projects undertaken by FASB and IASB (Hopkins et al., 2008).

\section{February 2006}

The FASB and the IASB drafted a Memorandum of Understanding in which they identified several more major convergence projects (Tyson, 2011).

\section{December 2007: Sec Drops the Reconciliation Requirement}

As per the SEC regulations, all foreign issuers registering with the SEC have to file their periodical financial reports in accordance with US GAAP, or in accordance with their local GAAP (IFRS), "accompanied by reconciliation with the US GAAP." This requirement of preparing and filing two sets of financial statements under two different sets of accounting standards resulted in considerable effort and cost to foreign companies registered with the SEC (Erchinger \& Winfried, 2007). In December 2007, the SEC eliminated this very costly requirement (James, 2008). According to Posner (2008), the SEC "ushered in a mutual recognition regime - a form of sovereignty sharing, perhaps unprecedented in SEC history - by lifting the reconciliation requirement for foreign listed companies using IFRS." 


\section{August 2008: SEC Road Map}

On August 27, 2008, the SEC proposed a 'Road Map" in which deadlines were specified for US companies to adopt IFRS. The SEC also suggested that FASB and IASB would continue to work toward convergence through 2011. The gradual switch over to IFRS contained in the road map visualizes IFRS adoption by large filers on or before December 15, 2014, by medium-size companies on or before December 15, 2015, and by all other companies by December 15, 2016 (Morgan, 2008).

\section{February 2010: SEC Work Plan}

On February 24, 2010, the SEC Staff published a work plan. The purpose of the work plan was to consider specific areas and factors relevant to a Commission determination in 2011 as to whether, when, and how our current financial reporting system for US issuers should be transitioned to a system incorporating in its statement, the SEC outlined a "Work Plan" to enable the SEC to evaluate the basic merits of IFRS and the key issues involved in transition to IFRS (SEC, 2010). The policy statement and the work plan did not contain specific suggestions on adoption dates or transition methods other than an observation that required initial adoption would not be likely to occur before 2015 or 2016 (Erchinger, 2012). The SEC did not make convergence as a pre-condition for adoption of IFRS. "Indeed, if standards are completely (identically) converged, the decision of adoption of IFRS would be moot" (Henry \& Holzmann, 2011).

\section{The First Push Back}

In October 2010, the chairs of FASB and IASB announced a postponement of the deadlines set for completing the convergence projects from June 2011 to the end of 2011. In April 2011, the two chairs again announced in a joint statement that they have decided to extend the time table for completing a few priority convergence projects for a few more additional months to enable them, to check whether our conclusions would stand the test of time, and to ensure that the standards are of the highest quality.

\section{October 2010 SEC Progress Report}

In October 2010, the SEC Staff published a "Progress Report" that contained discussions on each section of the Work Plan and provided an update of the Staff's efforts and some preliminary observations. The Report mentioned that the Staff's research showed that other jurisdictions in general incorporated IFRS into their reporting requirements by either 1) full use of IFRS as issued by the IASB or 2) use IFRS after some form of local variation.

\section{Adoption}

The first category could be considered as "adoption," the purest form of incorporating IFRS. Under this method, countries make no changes to the standards issued by the IASB and incorporate the IFRS without any approval of any local body or authority. Incidentally, adoption of IFRS is the standard path that the IASB has stipulated in its IFRS 1, "First Time Adoption of IFRS" (Ohlgart \& Ernst, 2011). This method is seen as resulting in a much greater degree of relegation of the local regulatory authority and responsibility for investor protection to a global private sector and independent standard-setting body with a multinational constituent bases. The SEC Staff's research showed that, so far, a very small minority of the largest jurisdictions currently follows the 'adoption' approach (SEC Progress Report, 2010).

The second category, mentioned above, consists of countries that use IFRS after some form of a national modification process. Under this method, there is no guarantee that the local standards would be identical to the IFRS as issued. This second category may be further subdivided into 1) those jurisdictions that converge their local standards with the IFRS without a full commitment to fully adopt IFRS as issued by IASB: and 2) those jurisdictions that undertake some form of local endorsement for incorporating the IFRS. The first of these subdivisions is now known as 'convergence' and the second, as 'endorsement' (SEC Progress Report, 2010). 


\section{Convergence}

According to Marks et al. (2009), convergence is the name given to the efforts to ensure that public companies follow the same accounting principles around the world. Under convergence, ultimately GAAP accounting standards will cease to exist and public business world-wide will use IFRS. Convergence implies that over a period of time, the differences between the GAAP standards and the IFRS standards would be minimized to such a degree where US would be adopting IFRS almost automatically or very close to it without the application of IFRS 1. Prior to 2011, a significant number of converged standards have been issued by FASB or IASB. Currently, some priority convergence projects, such as Revenue Recognition, are still in process (Ohlgart \& Ernst, 2011). With the G-30 finance ministers having recently given their standard-setters a new deadline of mid-2013 to get their convergence work done, the SEC is under renewed pressure to reach a decision on incorporating IFRS (Cohn, 2012). The goal of the convergence approach is to continue natural convergence of the two sets of standards through the joint efforts of FASB and IASB until a point of immaterial differences is reached, where financial statements are comparable no matter what set of standards are used (Ohlgart \& Ernst, 2011).

\section{Endorsement}

A vast majority of jurisdictions in the SEC Staff's sample seem to be following the 'endorsement approach.' Under the 'endorsement' method, countries incorporate an IFRS standard into their own jurisdiction's standards, at times, after some local variation. The degree of deviation from the IFRS standard as issued by the IASB varies in this approach. Some countries adopt standards exactly as issued by the IASB. Some others make modifications to meet their country-specific issues. Endorsement method also involves an activity of reviewing new standards after adoption or convergence. Thus, any standard issued by the IASB would be subject to review while local regulators continue to be in control of issuing accounting standards. Endorsement leads to a possibility of different versions of the same IFRS being applied worldwide and the purpose of transparency and comparability would be impaired (Ohlgart \& Ernst, 2011).

\section{December 6, 2010: Beswick's Condorsement Concept}

Speaking at the 2010 AICPA National Conference on current SEC and PCAOB Developments on December 6, 2010, Paul Beswick, Deputy Chief Accountant of the SEC, 'pondered aloud' about a concept he termed as "condorsement" for incorporating IFRS into the GAAP (Whitehouse, 2011). Beswick (2010) stated:

Very few jurisdictions were looking directly to the IASB as the mechanism for providing authoritative support for the standards followed by a jurisdiction. In talking with our foreign regulatory counterparts, other national standard setters, and others, the reasons are varied - from addressing legal requirements to the desire to maintain some level of national sovereignty. To give you an example, India is set to move to IFRS in 2011. However, they describe their approach as a convergence approach to IFRS and have indicated that they may not fully adopt IFRS if they believe an exception is warranted. In our October update we highlighted that the majority of jurisdictions are following either a convergence or an endorsement approach. In my opinion, if the U.S. were to move to IFRS, somewhere in between could be the right approach. I will call it a "condorsement" approach. Yes, I admit I just made up a word. And by the way, the patent is pending as we speak. (Beswick's remarks available at: http://www.sec.gov/news/speech/2010/spch120610pab.htm)

\section{May 2011 SEC Staff Paper}

As Lamareaux (2011) describes, nearly a decade after FASB and IASB agreed to converge their standards after subscribing to the historic "Norwalk Agreement," the SEC floated a concept in May 2011 that would redefine convergence and establish the FASB as an endorsement body standards in the US. The SEC Staff Paper issued in May 2011 introduces a new possible method of incorporation of IFRS, now famously known as "condorsement." This new method, discussed in the SEC Staff Paper of May 2011, has the objective of allowing a US issuer that is in compliance with the US GAAP to be able to also state that it is in compliance with the IFRS as issued by the IASB (Neal, 2011). 
At the very outset of the Staff Paper, the SEC made it plain that the Commission has not yet made any decision as to when, and if so, how, to incorporate the IFRS into the financial reporting system for US users. The focus of the Staff Paper, as stated is to outline a possible approach for the incorporation ... if the Commission were to decide that incorporation of IFRS is in the best interests of US investors. The Staff Paper does not provide an extensive discussion of the potential timeline of incorporation, since timeline for incorporation is a separate consideration. The Staff's discussion of the framework in the Staff Paper illustrated the following:

- $\quad$ The decision faced by the commission, in an effort to achieve a single set of high-quality, globally accepted accounting standards, is not necessarily a 'binary' decision (i.e., either to require the use of IFRS by all US users immediately or not).

- Incorporation of IFRS is not inconsistent with the SEC maintaining its ultimate authority over US accounting standard setting, and

- $\quad$ There are potential ways to accomplish the broad objectives of pursuing a single set of high-quality, globally accepted accounting standards while minimizing cost, effort and other transition obstacles (SEC Staff Paper, 2011).

\section{Condorsement}

This 'condorsement' approach, as mentioned earlier by Beswick (2010), seeks to merge the ideas of convergence and endorsement and leads to a process by which IFRS would be incorporated into the GAAP through a process led by the US GAAP instead of IASB. According to Whitehouse (2011), the condorsement idea would infuse IFRS into the US GAAP by endorsing international standards one at a time while also simultaneously continuing to converge them to the GAAP. This would lead to a gradual transfer to IFRS, with the differences between IFRS and GAAP eliminated over time through further US standard setting (Whitehouse, 2011).

This process of incorporation would be slower than the present convergence process, would take at least five to seven years, and would leave IFRS transition completely controlled by the US regulators. Furthermore, FASB would incorporate new and amended IFRS into the US GAAP through an endorsement process which would give FASB the authority to modify IFRS before incorporation. Under this method, the FASB would remain in control as the standard-setter responsible for issuing US GAAP and also continue to participate in the process of developing IFRS (Street, 2012).

\section{SEC Final Staff Report and the Final Pushback}

On July 13, 2012, the SEC Staff issued its "Final Report on the Work Plan." In the preface to the Report, the SEC Staff emphasizes that publication of the Report does not imply - and should not be construed to implythat the Commission has made any a policy decision or even a recommendation as to whether, IFRS should be incorporated into the financial reporting system for in US users, or how such incorporation, if it were to occur, should be implemented (Zell \& Rapp, 2012). In the Final Report, the SEC Staff identified seven areas bearing on the need for further study, summarized by Zell and Rapp (2012) as follows:

- The Staff identified several IFRS areas as continuing to be underdeveloped. These areas include accounting for extractive industries, insurance and rate-regulated industries among others.

- The interpretive body of IFRS, the "IFRS Interpretations Committee." Has not demonstrated the ability to review and provide authoritative guidance on a timely basis.

- $\quad$ There still exists significant diversity in practice or interpretive guidance in multiple jurisdictions.

- $\quad$ The Staff's review of financial statements prepared in accordance with IFRS led to a conclusion that global application of IFRS could be improved to narrow diversity.'

- The Staff believes that without further mechanisms put in place, the overall design and governance structure of the IFRS Foundation, the governing body of the IASB, may not be able to sufficiently protect the US capital markets. The IASB does not have such a mandate in place.

- $\quad$ There is concern for adequate future funding of the IFRS Foundation. The Staff observed that the IFRS Foundation is a private, not-for-profit organization that ultimately has no ability to require or compel funding. 
- $\quad$ The Staff notes that, at present, investor education on accounting issues and changes in accounting standards is not uniform today and believes that more consideration is needed to improve investor education.

(Source: Zell \& Rapp, 2012)

Whitehouse (2013) states that, while the SEC Staff claims that there is a need for further analysis and consideration before a decision or a recommendation can be made by the Commission, the final report provides no timeline for when such analysis or final recommendation might be completed. However, the Report contains many reasons as to why the SEC should be cautious. According to Zell and Rapp (2012), the SEC Staff, with its Final Report, quashed any near term prospects of IFRS replacing the GAAP. Hoffelder (2013) opines that the Staff expresses hesitation about merging IFRS and GAAP and thereby renders that goal a little more remote, and also that the Final Report makes it very clear that putting IASB in the driver's seat would be out of question. Rosivich (2012) comments that the "SEC Road Map" is history and that the question of "when" the changeover from GAAP to IFRS might occur has changed to "whether" following the SEC Staff's Final Report.

In a response to the issues raised in the SEC Staff Final Report (2012), the IFRS Foundation Staff published a report of its own, challenging the SEC Staff's averments. The IFRS Foundation report says that SEC's indecision creates a risk to the convergence efforts that had been underway between FASB and IASB for over a decade. The IFRS Foundation Report also mentioned that there is a risk that, in the absence of a US decision on adoption of IFRS, a decade of 'convergence' may be followed by a new decade of 'divergence' (Whitehouse, 2012).

\section{SUMMARY AND CONCLUSIONS}

The US GAAP have been put in place through a meticulous process of intense deliberation and these GAAP stood the test of time for over four score years, all the while being regarded all over the world as the gold standard for financial accounting and reporting. With the advent of multi-national corporations, sweeping changes in global capital markets and cross-border investment opportunities, there emerged a demand for a single set of globally applicable financial reporting standards. The IASC was established in 1972 and the IASB, formed in 2001, began issuing IFRS. From the beginning, the SEC and the FASB gave their support towards developing globally applicable accounting standards. The first formal step is taken in 2002 when FASB and IASB signed an MOU, known as the 'Norwalk Agreement,' recognizing convergence of the GAAP and IFRS as their avowed goal. It was followed by several more MOUs, the 2006 SEC Road Map, the 2010 SEC Work Plan, the 2011 SEC Staff Paper, and final, the 2012 SEC Staff Final Report. During this period, a lot of effort was put in towards convergence. However, as more progress was being made on projects of convergence several more roadblocks and second thoughts about the incorporation of IFRS into the U S financial reporting system began to surface, as was evidenced by the contents of the SEC Staff's Final Report of 2012. With the issuance of the Final Report, there ensued a definite Push Back in the SEC's efforts towards incorporation of IFRS into the US GAAP. The US standard setters are now realizing that more analysis of the process is absolutely needed before any further decisions can be made. There are many critics who are claiming that the principles-based IFRS would lead to flexible and undependable financial reporting standards. Some others are cautioning against US abdicating its sovereign authority over standard-setting to a private, non-U S organization. The present situation is in limbo. The SEC, in its latest Staff Final Report did not mention any possible further steps in the issues involved except that, as far as US standard setting is concerned, putting IASB in the driver's seat is out of question!

\section{RECOMMENDATIONS}

The topic of incorporation of IFRS into the US financial accounting and reporting system has been and continues to be a very important and current area for continuous research for quite some time into the future. Further research is needed to explore a possible solution to this present impasse and the possible ways of incorporation of IFRS other than convergence, endorsement, and condorsement. More than 120 countries are already adopting IFRS in some manner. Can the US choose to be outside the main stream? Can there be a single set of high-quality, globally applicable financial reporting standards without the involvement of United States, the largest economy with the largest capital markets in the world? These questions need to be answered. Research is also needed to study the impact of this present non-decision of the SEC on the business education students and faculty in the US and also the impact on the public accounting profession. 


\section{AUTHOR INFORMATION}

RamMohan R. Yallapragada, Ph.D., is a Professor of Accounting at Fayetteville State University. He obtained his $\mathrm{PhD}$ degree in Accounting from the University of Houston. He holds a CPA certificate from the State of Louisiana. His research areas include cost accounting in healthcare, accounting irregularities in Fannie Mae, impact of Sarbanes-Oxley Act of 2002 on American corporations, and issues involved in incorporation of IFRS in the United States. E-mail: ryallapr@uncfsu.edu (Corresponding author)

C. William Roe, Ph.D., received his doctorate from Mississippi State University in Management. He has published numerous journal articles in management, marketing, healthcare administration, and international business. He currently serves as Associate Dean and Director of Graduate Business Programs at Arkansas State University. He has consulted extensively with numerous public, private, for-profit, and not-for-profit organizations in the areas of strategic planning, leadership, organizational change and development, and management development. E-mail: broe@astate.edu

Alfred G. Toma, Ph.D., is an Assistant Dean of Administration at the University of Louisiana, Lafayette. He holds the degrees of M.B.A. from the American University of Beirut, Lebanon and M.Sc in Marketing from Louisiana State University. He has published several journal articles and conference papers in the areas of international business and entrepreneurship. He currently teaches courses in international business management, entrepreneurship, and human resources management at the University of Louisiana at Lafayette. His extensive actual business and consultancy experiences are focused on the areas of entry and operations in Middle East markets and entrepreneurial ventures start-ups. E-mail: agt5159@louisiana.edu

\section{REFERENCES}

1. Blaszczynski, C., James, M. L., \& Cruz, C. (2012). Global financial reporting and the future of U S Generally Accepted Accounting Principles. Journal of Global Business Education, 12, 1-10.

2. Cohn, M. (2012). Chipman sees SEC's IFRS decision coming soon. Accounting Today, 26(6), 51-52.

3. Erchinger, H. (2012). IFRS in the United States-developments and current status. Australian Accounting Review, 22(3), 248-256.

4. Erchinger, H., \& Melcher, W. (2007). Convergence between US GAAP and IFRS: Acceptance of IFRS by the US Securities and Exchange Commission (SEC). Accounting in Europe, 4(2), 123-139.

5. Gundewadi, B. B., \& Paragouda, M. R. (2013). Challenges and opportunities faced by Indian companies for application of IFRS. Golden Research Thoughts, 3(2), 1-3.

6. Henry, E., \& Holzman, O. J. (2011). FASB's progress toward convergence: Expeditious but thoughtful. Journal of Corporate Accounting \& Finance, 22(5), 97-100.

7. Hoffelder, K. (2013). SEC report backs away from convergence. CFO Magazine, October 2013.

8. Hopkins, P. E. et al. (2008). Response to the SEC release, 'Acceptance from foreign private issuers of financial statements prepared in accordance with International Financial Reporting Standards without reconciliation to U.S. GAAP File No. S7-13-07.' Accounting Horizons, 22(2), 223-240.

9. James, M. (2008). Accounting majors' ability to identify financial reporting errors and omission and the convergence between U.S. GAAP and International Financial Reporting Standards. Proceedings of the Academy of Accounting \& Financial Studies, 13(2), 14-18.

10. Lamareaux, M. G. (2011). Beyond convergence. Journal of Accountancy, 212(2), 46-51.

11. Legotte, L. C. (2012). IFRS adoption in the United States in 2015. Glabal Articles, August 24, 2012, 1-8.

12. Marks, H. M. et al. (2009). Appendix F: Accounting principles - GAAP and IFRS. In The Handbook of Financing Growth: Strategies, Capital Structure, and M\&A Transactions (Second ed., p. 587). Hoboken, NJ: John Wiley \& Sons, Inc.

13. McEnroe, J. E., \& Sullivan, M. (2012). CPAs' and CFOs' perceptions regarding principles-based accounting standards. CPA Journal, 82(3), 32-37.

14. Morgan, J. (2008). SEC launches international accounting road map proposal to be monumental undertaking for U.S. Companies. Money Management Executive, 16(46).

15. Neal, T. L. (2011). SEC's Staff Paper exploring a possible method of incorporating IFRS into the financial reporting system for US issuers. GAAP Update Service, 11(18), 1-4. 
16. Ohlgart, C., \& Ernst, S. (2011). IFRS yes, no, maybe: What US companies need to know. Financial Executive, 27(8), 39-43.

17. Phillips, L. J. (2010). The implications of IFRS on the functioning of the Securities Antifraud Regime in the United States. Michigan Law Review, 108(4), 603-631.

18. Poon, W. W. (2010). SEC work plan for the consideration of incorporating IFRS into the U.S. financial reporting system. Proceedings of the Northeast Business \& Economics Association 2010, 101-104.

19. Ramana, K. (2012). The question of IFRS adoption: A very long engagement. CPA Journal, 82(4), 11.

20. Rosivich, A. (2012). Not a good year for IFRS adoption in the US. AccountingWEB, posted on December 24, 2012.

21. Ruder, D. S. et al. (2005). Creation of worldwide accounting standards: Convergence \& independence. Northwestern Journal of International Law and Business, Symposium on the Convergence of Accounting Standards, Spring 2005.

22. Securities and Exchange Commission (2010). Progress report. Office of the Chief Accountant, Division of Finance, SEC, October 29, 2010.

23. Securities and Exchange Commission (2011). Exploring a possible method of incorporation: Staff paper. Office of the Chief Accountant, Division of Finance, SEC, May 26, 2011.

24. Street, D. L. (2012). IFRS in the United States: If, when and how? Australian Accounting Review, 22(3), 257-274.

25. Tyson, T. (2011). The convergence of IFMS and US GAAP. CPA Journal, 81(6), $26-31$.

26. Whitehouse, T. (2011). SEC staff flesh out 'condorsement' to IFRS. Compliance Week, 8(90), 8.

27. Whitehouse, T. (2012). SEC report on IFRS: Reasons for caution but no decision. Compliance Week, 9(103), 6.

28. Zell, E. S., \& Rapp, R. N. (2012, July 25). SEC staff drops support for near-term adoption of IFRS. Lexology, Association of Corporate Counsel. Retrieved from http:// www. lexology.com/library/detail 